New North Star, 2021; 3:64-66

\title{
“Is God Dead?": Frederick Douglass's Recollection of a Contentious Moment in Antislavery History
}

\section{Edited by Alex Schwartz IUPUI}

One of the most dramatic ideological confrontations in the history of Black abolitionism occurred when Sojourner Truth interrupted a speech in which Frederick Douglass advocated violent antislavery tactics by posing the question "Is God dead?" While it is one of the best remembered of Truth's public remarks, historians have found contradictory evidence about where and when this confrontation occurred. An 1885 letter from Douglass to Rhode Island antislavery journalist Elizabeth Chace Wyman (1847-1929), reproduced below, provides his most complete recollection of the event. ${ }^{1}$

Truth's question is memorialized on her gravestone, and it embodies her spiritual and moral courage as an antislavery activist. Truth believed God had a central role in the quest towards the abolition of slavery; she placed God's will over human agency. Truth's question highlights the connection between Christianity and the antislavery movement, her role as a Black female abolitionist, and her ability to question men and figures of authority despite the social consequences of doing so.

Sojourner Truth and Frederick Douglass were both prominent abolitionists and orators who regularly traveled the country to participate in antislavery gatherings. Early in their careers they both aligned with Garrisonian principles of nonviolence, nonparticipation in politics, and moral suasion. Truth remained with the Garrisonians, while Douglass split from them in the early 1850s. He had come to believe that moral suasion, or appealing to the good consciences of Americans by describing the inhumanity of slavery, was not enough to stop the Slave Power's hold on the government and that it was ineffective when fighting against the violent system of chattel slavery. Events like the passage of the Fugitive Slave Act of 1850 persuaded Douglass that violent action might be necessary to defeat slavery. Douglass's and Truth's ideologies were in tension, therefore, at their famous confrontation at this antislavery meeting.

In Sojourner Truth: A Life, a Symbol (1996), Nell Irvin Painter writes that Truth said, "Is God dead?" when she interrupted a Douglass speech in Boston's Faneuil Hall in 1860. Painter cites accounts from Wendell Phillips that were published by Harriet Beecher Stowe, first in the New York Independent in 1860 and later in the Atlantic Monthly in 1863. Painter describes Stowe's articles as fiction rather than fact. ${ }^{2}$ Stowe's original article was written to oppose President James Buchanan's belief that the Constitution legalized slavery; he wanted to add an amendment that clarified that slavery was legal and that the abolitionists should stop organizing to end slavery. ${ }^{3}$

Carleton Mabee, author of Sojourner Truth: Slave, Prophet, Legend (1993), found evidence of the incident from Philadelphia journalist Oliver Johnson (1809-1889), who was in attendance at an Ohio Anti-Slavery Society meeting in 1852. Johnson's article in the Pennsylvania

\footnotetext{
${ }^{1}$ Courtesy of the Department of Psychiatry, Vanderbilt University, Personal Collection of Professor Marc H. Hollender.

${ }^{2}$ Nell Irvin Painter, Sojourner Truth: A Life, a Symbol (New York: W. W. Norton, 1996), 161-62; Harriet Beecher Stowe, "The President's Message," Independent, 20 December 1860; Harriet Beecher Stowe, "Sojourner Truth, Libyan Sibyl," Atlantic Monthly 11 (April 1863), 473-481.

${ }^{3}$ Carleton Mabee, Sojourner Truth: Slave, Prophet, Legend (New York: NYU Press, 1993), 83.
} 
Freeman reported that Truth said "Is God gone?" and not "Is God dead?" Mabee also draws from newspaper accounts in the National Anti-Slavery Standard, The Liberator, the Anti-Slavery Bugle, and Frederick Douglass' Paper to supply fuller details of the event. Also, Mabee could not find any evidence confirming Phillips's attendance at either the 1852 Ohio or 1860 Faneuil Hall antislavery meetings, which discredits Stowe's reporting of the event. ${ }^{4}$

Neither Painter nor Mabee cite the following letter to Elizabeth Chace Wyman from Frederick Douglass, which sheds more light on what one contemporary historian has dubbed the "Douglass-Truth Debate." 5 In Douglass's 1881 autobiography, Life and Times of Frederick Douglass, he recalls that his exchange with Truth had occurred at an antislavery meeting in Salem, Ohio, but does not supply a date. ${ }^{6}$ Wyman wrote Douglass inquiring about more details of his dramatic interaction with Truth for her forthcoming article that was to be published in The New England Magazine. She quotes Douglass's recollections of the event (dated 24 March 1885) in her article. ${ }^{7}$ In his letter, Douglass recounts the incident as occurring at an 1852 Ohio antislavery convention, when Truth interrupted his address endorsing violence with the question "Is God dead?" Douglass's memory of the event closely matches Johnson's original reporting of it. He recalls the presence of many prominent Garrisonian abolitionists at that meeting who were very unsympathetic toward his changed views on politics and violent tactics. These included Joseph Barker (1806-1875), a political radical, minister, printer, and Garrisonian abolitionist who was active in antislavery agitation in England and the United States; Stephen Symonds Foster (18091881), a New Hampshire abolitionist and women's rights activist married to abolitionist Abby Kelley Foster and a prominent member of the Garrisonian American Anti-Slavery Society; and Parker Pillsbury (1809-1898), a Garrisonian abolitionist and Congregational minister from Massachusetts who went on frequent speaking tours with the Fosters and Wendell Phillips. ${ }^{8}$ Most significantly, Douglass shared with Wyman the audience's reaction to Truth's interjection. In Douglass's recollection, Truth's "Is God dead?" had brought not just himself but the entire meeting "to a stand still - just as we should have been if some one had thrown a brick through the window." Douglass's letter, reproduced below and prepared for publication in a future volume of The Frederick Douglass Papers, helps to clarify important details of an event that historians have long recognized as emblematic of contentious ideological disputes in the antislavery struggle.

\footnotetext{
${ }^{4}$ Mabee, Sojourner Truth, 84.

5 Tim Bruno, "Rewriting Rebellion: The Douglass-Truth Debate," ESQ 65 (2019), 33-72.

${ }^{6}$ John R. McKivigan, The Frederick Douglass Papers, Series 2: Autobiographical Writings, 3 vols. (New Haven, Conn.: Yale University Press, 1999-2012), 3:215.

${ }^{7}$ Lillie Buffum Chace Wyman, "Sojourner Truth,” The New England Magazine 24 (March 1901), 63.

${ }^{8}$ Betty Fladeland, Abolitionists and Working-Class Problems in the Age of Industrialization (Baton Rouge: Louisiana State University Press, 1984), 132-33, 136, 138, 143; Leslie Stephen, ed., “Joseph Barker,” Dictionary of National Biography (London: 1885), 206; John R. McKivigan, “The Antislavery 'Comeouter' Sects: A Neglected Dimension of the Abolitionist Movement," History of the American Abolitionist Movement (New York: Garland, 1999), 143; Wilbert L. Jenkins, Climbing Up to Glory: A Short History of African Americans during the Civil War and Reconstruction (Wilmington, Del.: Rowman and Littlefield Publishers, 2002), 217; Andrea Moore Kerr, Lucy Stone: Speaking Out for Equality (New Brunswick, N.J.: Rutgers University Press, 1995), 139; David W. Blight, Frederick Douglass: Prophet of Freedom (New York: Simon and Schuster, 2018), 98, 136; Stacey M. Robertson, Parker Pillsbury: Radical Abolitionist, Male Feminist (Ithaca, N.Y.: Cornell University Press, 2000), 5.
} 
[Washington, D.C.] 24 March 1885[.]

\section{My DEAR MRS WyMAN:}

The incident to which you allude occurred at an antislavery meeting in Salem Ohio: addressed by Parker Pillsbury, Stephen S. Foster, Joseph Barker and others. It was after I had become a voting abolishonist and when therefore, I was not in harmony with the non voters and the meeting there assembled - but I was either called out or called myself out I forget which-In my speech I took the ground that Slavery could only go down in blood - that Slaveholders and the country had sinned too long and too deeply to escape. While describing the power of Slavery in the church and the state in furtherance of my argument, Sojourner in a distant part of the "Hall" startled me and the whole audience with the question "Is God dead?" The suddenness and sharpness together with its impertenence brought me for a moment to a complete halt. I had said nothing that called for such a question but gave it a negative answer and went on with my speech. I have never been able to see why such an incident should be so often referred to. The effect of the question was much in the tone in which it was asked - and the moment in my speech when it came. It has been said I was completely unhorsed and discomfitted by the question. Perhaps I was, but as I remember my condition at the time, I was about as self-possessed as was my audience. We were all for the moment brought to a stand still- just as we should have been if some one had thrown a brick through the window.

I was very glad to receive your letter and hear of your dear Mother-I have often thought of the pleasant time Helen and myself had in your dear circle.

Please remember me kindly to your much respected Mother and Mr Wyman and your curlly headed boy.

Very truly yours

FREDK DOUGLASS

[P.S.] Mrs Douglass has just come in and sends love. 